\title{
Esterase variation among Argentine populations of Trimerotropis pallidipennis (Orthoptera)
}

\author{
VA Confalonieri, JC Vilardi, BO Saidman \\ Universidad de Buenos Aires, Faculdad de Ciencias Exactas y Naturales \\ Departamento de Ciencias Biológicas, 1428 Buenos Aires, Argentina
}

(Received 4 January 1989; accepted 10 March 1990)

\begin{abstract}
Summary - Isozyme studies were carried out in 3 populations of Trimerotropis pallidipennis from Tucumán and San Luis Provinces (TU, $\mathrm{SL}_{1}$ and $\mathrm{SL}_{2}$ ) (Argentina). The purposes of this study were: determination of the numbers of genes and alleles involved in the production of the isozymes and their frequencies, detection of diagnostic loci for population identification and measuring the genetic variability and the degree of genetic differentiation among populations. With this aim, the esterase (EST) isozyme system was studied and 6 loci were analysed (Est 1 to Est 6 ). The EST patterns allowed population samples from different biogeographic provinces to be distinguished. Qualitative differences between populations were observed in the expression of some loci (Est 1, Est 2 and Est 3) and the presence of additional alleles for other ones (Est 5 and Est 6), characterizing TU, were also detected. Therefore, this differentiation among populations refers to both gene expression and allelic frequencies which may represent 2 distinct responses to environmental differences. Possible correlations of genetic and chromosomal variation are also discussed.
\end{abstract}

orthoptera / isozyme / esterase / Trimerotropis / genetic variation

Résumé - Variabilité des estérases dans des populations argentines de Trimerotropis pallidipennis (Orthoptères). Trois populations de Trimerotropis pallidipennis situées dans les provinces de Tucumán et San Luis (TU, $S L_{1}$ et $S L_{2}$ ) (République argentine) ont été étudiées afin de déterminer le nombre de gènes et d'allèles responsables de la synthèse des isoenzymes estérasiques, d'identifier les locus pouvant caractériser des populations, et d'évaluer la variabilité et le degré de différentiation génétique entre les populations. Six locus probables (Est 1 à Est 6 ) ont été reconnus. Les enzymogrammes estérasiques ont permis de distinguer les échantillons des différentes provinces biogéographiques, tandis que ceux de la même province ne pouvaient pas être distingués. Il existe, entre les populations, des différences qualitatives dans l'expression des locus Est 1, Est 2 et Est 3 et ainsi que dans la présence d'allèles différentiels aux locus Est 5 et Est 6. Cette différence entre les populations se manifeste aussi bien dans l'expression des gènes que dans les fréquences alléliques, ce qui pourrait représenter 2 types de réponses adaptatives. Les corrélations entre la variabilité génétique et chromosomique sont discutées.

orthoptère / isozyme / estérase / Trimerotropis / variabilité génétique 


\section{INTRODUCTION}

Grasshopper species of the genus Trimerotropis are of interest from an evolutionary genetics standpoint because they show chromosomal variation with respect to the position of the centromere (White, 1973), usually considered as produced by pericentric inversions (Hewitt, 1979; John, 1983).

Most of the species of this genus inhabit arid regions from Western North America; $T$ pallidipennis is one of the few Trimerotropines to have successfully extended its distribution to Andean South America (White, 1973). Argentine populations studied are polymorphic for pericentric inversions (Mesa, 1971; Vaio et al, 1979; Goñi et al, 1985; Confalonieri, 1988; Confalonieri and Colombo, 1989).

Goñi et al (1985) observed for this species a geographical pattern of chromosomal polymorphisms associated with neither phytogeographical nor climatic characteristics. Clinal variation along an altitudinal gradient of these polymorphisms was recently found (Confalonieri and Colombo, 1989). There is, therefore, a need for a more exhaustive ecological approach. This requires a parallel study of chromosomal, genetical and ecological variation.

In spite of the known usefulness of isozymal studies to population genetics, only a few studies (Moran et al, 1980; Gill, 1981; Halliday et al, 1983; Nevo et al, 1984; Chapco and Bidochka, 1986) have been performed dealing with allozyme variation in grasshopper species.

In this work, isozyme studies were carried out in $T$ pallidipennis with the purposes of: a) estimating the number of responsible genes and their allelic frequencies; b) detecting diagnostic loci for populations; c) determining genetic variability and the degree of differentiation between populations; d) correlating genetic and chromosomal variation.

This paper reports the results obtained from the study of the esterase (EST) isozyme system in 3 populations of $T$ pallidipennis.

\section{MATERIALS AND METHODS}

Samples of adult grasshoppers were collected from Tucumán (TU) and San Luis $\left(\mathrm{SL}_{1}\right.$ and $\mathrm{SL}_{2}$, República Argentina. TU is located at Amaicha del Valle $(2040 \mathrm{~m}$ above sea level); $\mathrm{SL}_{1}$ is situated on the National Road No 7, $\mathrm{km} 792.5$, and $\mathrm{SL}_{2}$ on the same road at $\mathrm{km} 816$ (560 and $440 \mathrm{~m}$ above sea level respectively). The populations sampled belong to 2 different biogeographic provinces of the Chaco Dominion, Neotropical Region (Cabrera and Willink, 1973). TU is in the Prepuna while both SL populations are situated in the Chaco Biogeographic Province (fig 1).

Twenty-four individuals from TU, 29 from $\mathrm{SL}_{1}$ and 20 from $\mathrm{SL}_{2}$ were collected. After removal of the testes for chromosomal analysis, the grasshoppers were frozen and stored in liquid air until enzyme assays were done.

Extracts were obtained from the eviscerated head and thorax. Each individual was thoroughly homogenised in approximately $0.6 \mathrm{ml}$ of $0.1 \mathrm{~mol} / 1$ Tris- $\mathrm{HCl}, \mathrm{pH} 7.1$. The homogenate was centrifuged at $7000 \mathrm{rpm}$ for $10 \mathrm{~min}$ in a refrigerated centrifuge.

The electrophoresis was conducted in $7 \%$ polyacrylamide horizontal gels according to the technique of Cordeiro (1974). The system of gel and tray buffers was discontinuous Poulik, pH 7.9, modified by Schaal and Anderson (1974). 


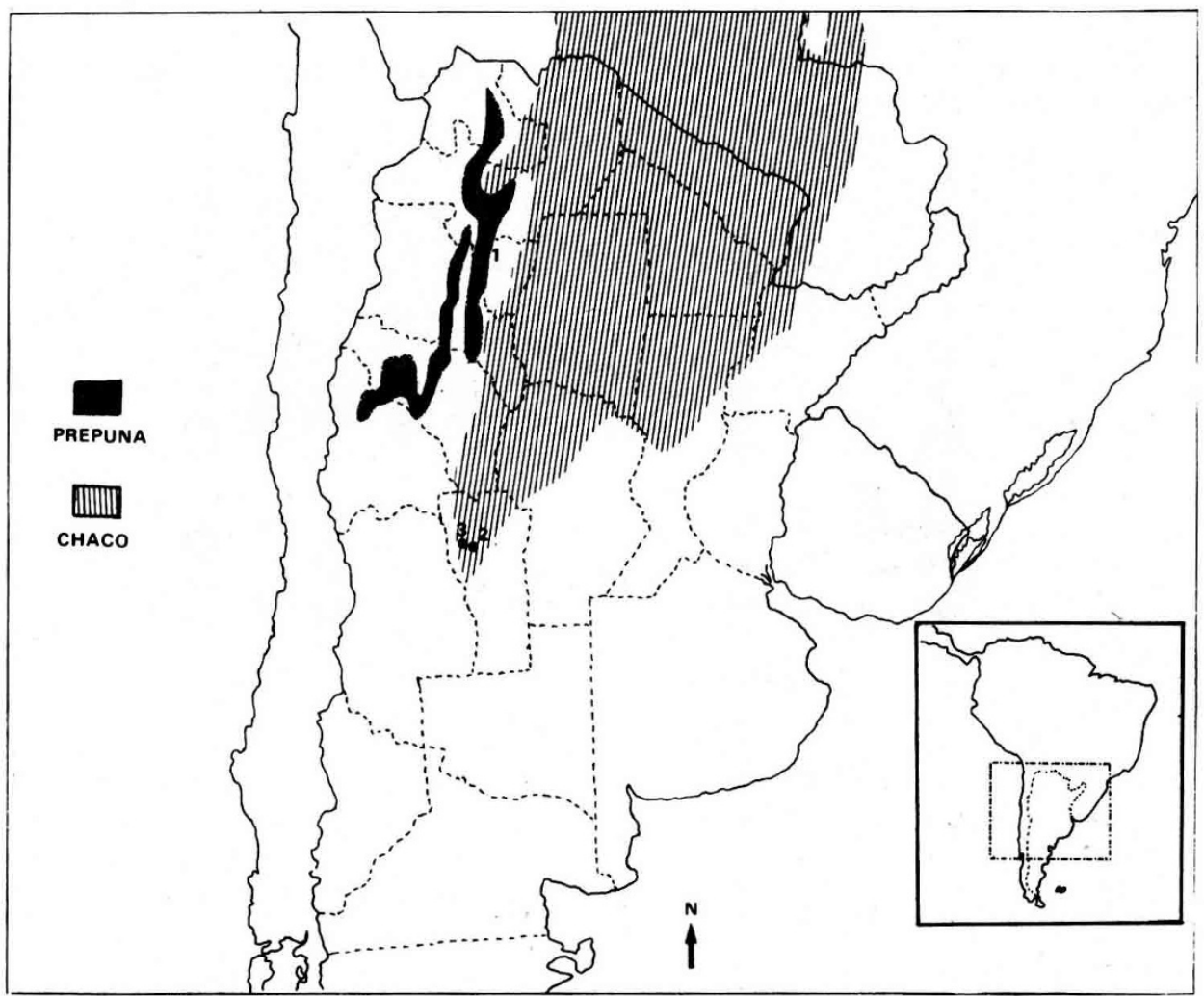

Fig 1. Map showing the 3 localities from Argentina where specimens of Trimerotropis pallidipennis were collected. Biogeographic Provinces according to Cabrera and Willink (1973). Tucumán: 1; San Luis 1: 2; San Luis 2: 3.

Staining techniques are described by Cladera (1981). Different substrates (esters) were used to characterize the different bands: $\alpha$-naphthyl acetate $(\alpha-\mathrm{NA}), \beta$ naphthyl acetate $(\beta$-NA), $\alpha$-naphthyl laurate $(\alpha$-NL), $\alpha$-naphthyl butyrate $(\alpha$ NB), $\alpha$-naphthyl oleate $(\alpha$-NO), $\alpha$-naphthyl propionate $(\alpha-\mathrm{NP})$ and naphthol AS-D acetate (AS-D).

The interpretation of the genetic variation in electrophoretic patterns is inferential according to Saidman and Naranjo (1982).

Bands are labelled in capital letters and numbered according to decreasing electrophoretic mobilities. Loci are named with an initial capital letter followed by lowercase letters and numbered according to decreasing mobilities of isoenzymes. Alleles are named with the symbol of their loci and an index according to decreasing mobilities of allozymes. 


\section{RESULTS}

Considering the 3 populations, 17 anodic bands were observed but only 12 (EST 1 to EST 12) could be analysed (fig 2).

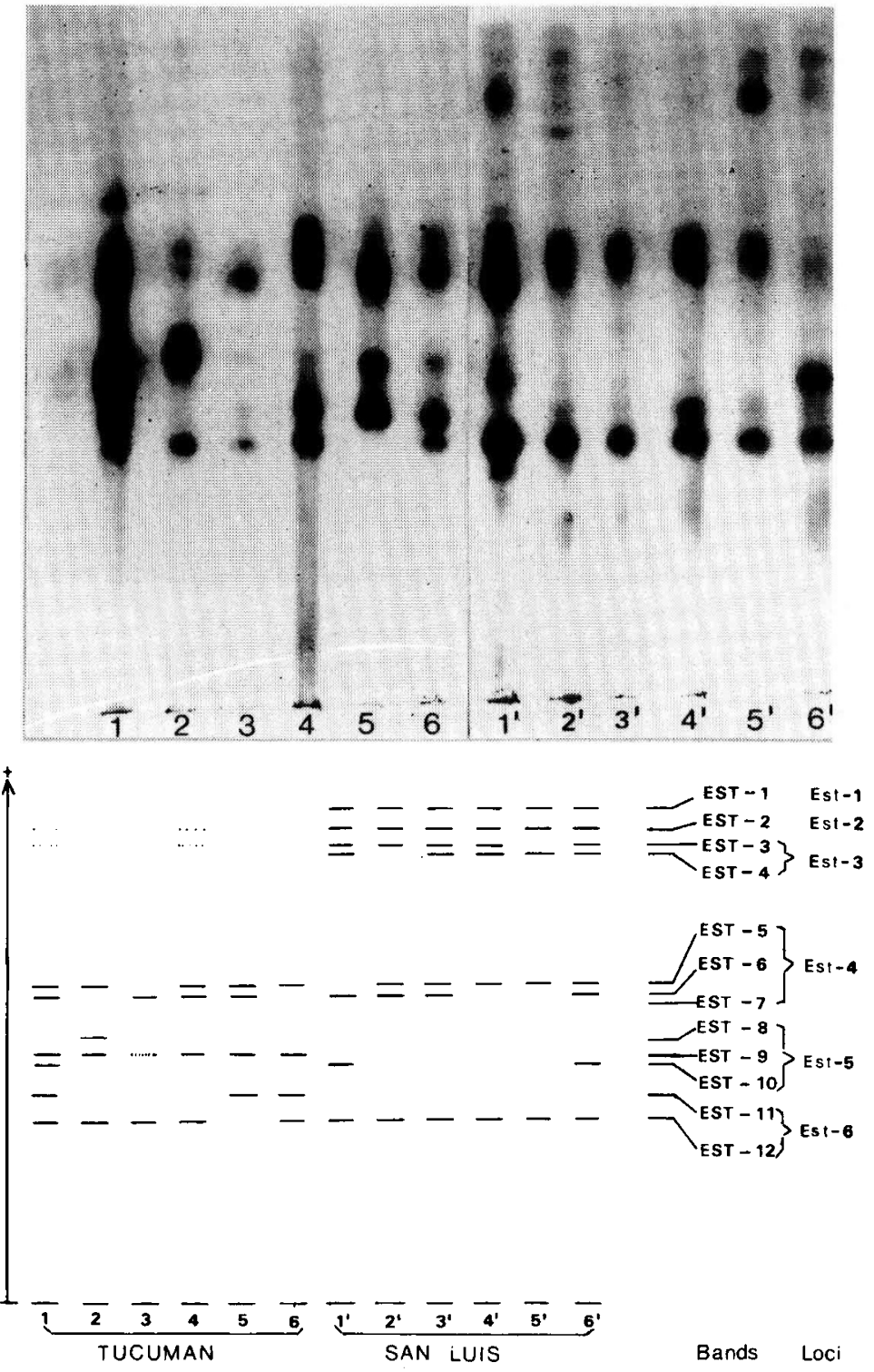

Fig 2. a) Some of the observed allozyme phenotypes for the esterase system. b) Schematic representation of bands from (a) and their possible genetic determination. 
The results obtained with different substrates are presented in table I. Bands could be grouped according to their ability to react with different esters: $E S T 1$ EST 2-EST 3; EST 4 - EST 5; EST 6; EST 7-EST 8; EST 9; EST 10 - EST 11 ; EST 12. The probable loci and alleles implicated in the genetic determination of bands were inferred taking into account the combinations of the differential substrate affinities.

Table I. Comparisons of staining affinities of bands with esterase activity.

\begin{tabular}{|c|c|c|c|c|c|}
\hline Bands & $\alpha-N a$ & $\beta-N A$ & $\alpha-N L$ & $\alpha-N S$ & $\alpha-N A+\beta-N A$ \\
\hline 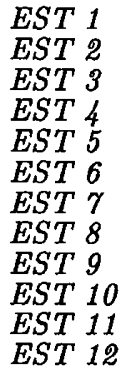 & $\begin{array}{l}+++ \\
+++ \\
+++ \\
+++ \\
+++ \\
+++ \\
+++ \\
++- \\
++- \\
++- \\
+++ \\
+++\end{array}$ & $\begin{array}{l}+-- \\
++- \\
++- \\
++- \\
+++ \\
+++ \\
+++ \\
+++ \\
+++ \\
+++ \\
++- \\
++-\end{array}$ & $\begin{array}{l}++- \\
+-- \\
++- \\
++- \\
++- \\
++- \\
++- \\
\text { NT } \\
--- \\
1-- \\
1--\end{array}$ & $\begin{array}{l}--- \\
+-- \\
1-- \\
1-- \\
--- \\
--- \\
--- \\
\text { NT } \\
1-- \\
1-- \\
+-- \\
+--\end{array}$ & $\begin{array}{l}+++(\alpha-\mathrm{NA}) \\
+++(\alpha-\mathrm{NA}) \\
+++(\alpha-\mathrm{NA}) \\
+++(\alpha-\mathrm{NA}) \\
+++(\alpha-\mathrm{NA}) \\
+++(\alpha \text {-NA } \\
+++(\alpha-\mathrm{NA}) \\
+++(\beta-\mathrm{NA}) \\
+++(\beta-\mathrm{NA}) \\
+++(\beta-\mathrm{NA}) \\
+++(\beta-\mathrm{NA}) \\
+++(\beta-\mathrm{NA})\end{array}$ \\
\hline Bands & $\alpha-N M$ & $\alpha-N B$ & $A S-D$ & $\alpha-N P$ & $\alpha-N O$ \\
\hline $\begin{array}{ll}E S T & 1 \\
E S T & 2 \\
E S T & 3 \\
E S T & 4 \\
E S T & 5 \\
E S T & 6 \\
E S T & 7 \\
E S T & 9 \\
E S T & 10 \\
E S T & 11 \\
E S T & 12\end{array}$ & $\begin{array}{l}--- \\
+-- \\
1-- \\
1-- \\
1-- \\
1-- \\
1-- \\
--- \\
+-- \\
+--\end{array}$ & $\begin{array}{l}+++ \\
--- \\
+++ \\
+++ \\
+-- \\
+-- \\
+-- \\
1-- \\
1-- \\
++- \\
++-\end{array}$ & $\begin{array}{l}-\overline{-} \\
1-- \\
+-- \\
+-- \\
++- \\
++- \\
++- \\
+-- \\
+-- \\
++- \\
++-\end{array}$ & $\begin{array}{l}+++ \\
+++ \\
--- \\
--- \\
+++ \\
+++ \\
+++ \\
++- \\
++- \\
+++ \\
+++\end{array}$ & $\begin{array}{l}--- \\
--- \\
--- \\
--- \\
--- \\
--- \\
--- \\
--- \\
--- \\
--- \\
---\end{array}$ \\
\hline
\end{tabular}

References: Staining intensities: $+++=$ very intense; $++-=$ intense; $+--=$ slight; / - = slight or absent; $---=$ absent. NT $=$ not tested.

$E S T 1$ and $E S T 2$ are invariable and may be produced by 2 monomorphic loci: $E S T 1$ and $E S T 2$ (fig 2). EST 3 and EST 4 show similar affinities and migrate very close to each other. Three kinds of patterns were observed: EST 3, EST 4 and EST 3 with EST 4. On these grounds the bands were considered as allozymes coded by 1 locus with 2 alleles, EST $3^{1}$ and EST $3^{2}$ respectively.

$E S T 1$ band was never observed in the TU population, and the expression of bands EST 2 to EST 4 in this sample was very poor or absent, showing some degree of individual variation.

$E S T 5, E S T 6$ and $E S T 7$ are also considered as allozymes. They appeared in the following combinations: EST 5; EST 6; EST 7; EST 5 with EST 6; EST 5 with $E S T$ 7; EST 6 with EST 7 (fig 2). Since the EST 7 band is at a low frequency, it is absent in the individuals depicted in figure $2 a$; in any case, its relative mobility is 
also indicated in 2b. The corresponding alleles were named; EST $4^{1}, E S T 4^{2}$ and EST $4^{3}$.

EST 8, EST 9 and EST 10 react similarly to $\alpha-$ and $\beta$-NA. EST 9 and EST 10 also gave similar staining affinities with the rest of the substrates employed. Because of its low frequency, EST 8 was absent in the individuals assayed with the latter substrates, and therefore its affinities could not be confirmed. Despite this fact, these results along with the combinations observed (EST 8; EST 9, EST 10; EST 8 with EST 9; EST 8 with EST 10; EST 9 with EST 10; absence of bands) may correspond to those expected for a locus with 4 alleles, 3 codominants, $E S T 5^{1}, E S T 5^{2}, E S T 5^{3}$ and 1 null EST $5^{0}$. The latter in a homozygous condition is characterized by the absence of bands. All phenotypes are shown in figure 2 except the combination EST 8 - EST 10 which appeared in other gels not depicted in this figure.

EST 11 and EST 12 varied showing the following combinations: EST 11; EST 12; EST 11 with EST 12. They were considered as produced by 1 locus with 2 alleles: $E S T \sigma^{1}$ and $E S T 6^{2}$ (fig 2). The bands corresponding to EST 6 could not be properly ascertained in 1 individual from $\mathrm{TU}$ and therefore it was excluded from the analysis of this locus.

Five additional bands, 4 between EST 4 and EST 5 and 1 between EST 10 and EST 11 were also found. Their respective affinities differentiated them from those of EST 1 to $E S T 12$, but their patterns were not constant enough to be unequivocally analysed.

Assuming that this genetic interpretation of bands is correct, phenotype and/or genotype frequencies for each locus were determined (table II). Then, allelic frequencies were estimated by counting or, in the case of the EST 5 locus which has a null allele, by the method of Neimann-Sorensen (1956) (table III). In addition, mean frequencies of heterozygotes per locus were also estimated and are indicated in table III.

From the 6 loci analysed, 4 displayed qualitative differences between TU and both SL populations. Thus, EST 1, EST 2 and EST 3, clearly expressed $\mathrm{SL}_{1}$ and $\mathrm{SL}_{2}$, were either absent or almost non detectable in TU. EST 6 was polymorphic in the latter and monomorphic in the other 2 populations.

The allelic frequencies at EST 3,EST \& and EST 5 were compared among populations by means of contingency tables (table III). Allelic frequencies of EST 3 from both SL populations were not statistically different and, at the EST 4 locus, differences were also not significant when all populations were considered (though in this case the $X^{2}$ for $\mathrm{SL}_{1}$ vs $\mathrm{SL}_{2}$ was significant at the $5 \%$ level). However, EST 5 locus significantly differentiates TU from both SL populations. This is due to the fact that EST $5^{\circ}$, the most frequent allele in $\mathrm{SL}_{1}$ and $\mathrm{SL}_{2}$, was absent in TU. Also, the EST $5^{2}$ frequency was high in TU and low in the other samples.

The average expected heterozygosity was also similar for $\mathrm{SL}_{1}$ and $\mathrm{SL}_{2}$ (about $0.24)$ and clearly different from that of TU (0.505) (table III).

In all populations, observed genotypic frequencies were compared with HardyWeinberg expectations by means of chi-square tests for the loci EST 3, EST 4 and EST 6 (table II). These statistics were further applied only to the data of EST 5 from TU because some classes were too small or absent in the other samples. In every case differences were not significant. 
Table II. Genotype frequencies of Esterase loci observed in 3 populations of $T$ pallidipennis from San Luis $\left(\mathrm{SL}_{1}\right.$ and $\left.\mathrm{SL}_{2}\right)$ and Tucumán (TU). $X^{2}$ statistics test for HardyWeinberg equilibrium (except for those cases where some genotypic classes were too small or absent) (the degrees of freedom are indicated in brackets).

\begin{tabular}{|c|c|c|c|}
\hline & $S L_{1}$ & $S L_{2}$ & $T U$ \\
\hline$E S T 1^{1 / 1}$ & 29 & 20 & not expressed \\
\hline$E S T 2^{1 / 1}$ & 29 & 20 & $\begin{array}{l}\text { absent or poorly } \\
\text { expressed }\end{array}$ \\
\hline$E S T 3^{1 / 1}$ & 5 & 2 & absent or poorly \\
\hline$E S T 3^{1 / 2}$ & 16 & 10 & \\
\hline$E S T 3^{2 / 2}$ & 8 & 8 & expressed \\
\hline$X^{2}$ & $0.388(1)$ & $0.196(1)$ & - \\
\hline$E S T 4^{1 / 1}$ & 9 & 6 & 7 \\
\hline $\operatorname{EST} 4^{1 / 2}$ & 12 & 8 & 7 \\
\hline $\operatorname{EST} 4^{1 / 3}$ & 1 & 4 & 2 \\
\hline$E S T 4^{2 / 2}$ & 6 & 1 & 4 \\
\hline $\operatorname{EST} 4^{2 / 3}$ & 1 & 0 & 3 \\
\hline $\operatorname{EST} 4^{3 / 3}$ & 0 & 1 & 1 \\
\hline$X^{2}$ & $0.270(1)$ & $1.424(2)$ & $1.607(2)$ \\
\hline $\operatorname{EST} 5^{1 / 1+1 / 0}$ & 0 & 0 & 2 \\
\hline$E S T 5^{1 / 2}$ & 1 & 0 & 5 \\
\hline $\operatorname{EST} 5^{2 / 2+2 / 0}$ & 1 & 1 & 8 \\
\hline$E S T 5^{2 / 3}$ & 5 & 1 & 7 \\
\hline $\operatorname{EST} 5^{3 / 3+3 / 0}$ & 8 & 5 & 2 \\
\hline $\operatorname{EST} 5^{1 / 3}$ & 2 & 0 & 0 \\
\hline $\operatorname{EST} 5^{0 / 0}$ & 12 & 13 & 0 \\
\hline$X^{2}$ & - & - & $4.061(2)$ \\
\hline $\operatorname{EST} \sigma^{1 / 1}$ & 0 & 0 & 3 \\
\hline $\operatorname{EST} 6^{1 / 2}$ & 0 & 0 & 6 \\
\hline$E S T \sigma^{2 / 2}$ & 29 & 20 & \\
\hline$X^{2}$ & - & - & $2.405(1)$ \\
\hline
\end{tabular}

\section{DISCUSSION}

The genetic interpretation of bands studied was inferential, but the hypotheses put forward agree with the fact that in all cases where statistical comparisons could be performed, observed genotypic frequencies fit very well with those expected according to the Hardy-Weinberg law.

Since 5 of the 6 loci analysed showed marked differences in either gene expression on allelic frequency, esterase zymogrames could be used to identify populations from different (but not from the same) provinces.

An additional difference between TU and SL populations is the level of variability of these loci. In the former, $H$ has more than twice the value it has in the latter.

The virtual lack of expression of EST 1 to EST 3 loci in TU may be explained by different (but not necessarily mutually exclusive) hypotheses: 
Table III. Allelic frequencies of esterase loci and expected frequencies of heterozygotes (H) estimated in 3 populations of $T$ pallidipennis from San Luis $\left(\mathrm{SL}_{1}\right.$ and $\left.\mathrm{SL}_{2}\right)$ and Tucumán (TU). (Degrees of freedom of chi square tests in brackets).

\begin{tabular}{|c|c|c|c|c|c|c|c|c|}
\hline \multirow[t]{2}{*}{ Gene } & \multicolumn{2}{|c|}{$S L_{1}$} & \multicolumn{2}{|c|}{$S L_{2}$} & \multicolumn{2}{|c|}{$T U$} & \multirow[b]{2}{*}{ Total } & \multirow{2}{*}{$\begin{array}{c}\text { Contingency } X^{2} \\
S L_{1} \text { vs } S L_{2}\end{array}$} \\
\hline & freq & $H$ & freq & $H$ & freq & $H$ & & \\
\hline$E S T 1^{1}$ & 1.000 & 0.000 & 1.000 & 0.000 & \multirow{2}{*}{\multicolumn{2}{|c|}{$\begin{array}{c}\text { not expressed } \\
\text { absent or poorly } \\
\text { expressed }\end{array}$}} & - & - \\
\hline$E S T 2^{1}$ & 1.000 & 0.000 & 1.000 & 0.000 & & & - & - \\
\hline $\begin{array}{l}E S T 3^{1} \\
E S T 3^{2}\end{array}$ & $\begin{array}{l}0.448 \\
0.552\end{array}$ & 0.494 & $\begin{array}{l}0.350 \\
0.650\end{array}$ & 0.455 & \multicolumn{2}{|c|}{ 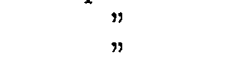 } & - & $\begin{array}{l}0.95 \\
(1)\end{array}$ \\
\hline $\operatorname{EST} 4^{1}$ & 0.535 & \multirow{3}{*}{0.528} & 0.600 & \multirow{3}{*}{0.555} & \multicolumn{2}{|l|}{0.480} & & \\
\hline$E S T 4^{2}$ & 0.430 & & 0.250 & & 0.375 & \multirow[t]{2}{*}{0.608} & 7.11 & 6.21 \\
\hline$E S T 4^{3}$ & 0.035 & & 0.15 & & 0.145 & & (4) & $(2)$ \\
\hline $\begin{array}{l}\operatorname{EST} 5^{0} \\
\operatorname{EST} 5^{1} \\
\operatorname{EST} 5^{2}\end{array}$ & $\begin{array}{l}0.540 \\
0.052 \\
0.122\end{array}$ & 0.609 & $\begin{array}{l}0.785 \\
0.000 \\
0.051\end{array}$ & 0.354 & $\begin{array}{l}0.000 ? \\
0.190 \\
0.580\end{array}$ & 0.575 & $\begin{array}{l}76.58^{* *} \\
(6)\end{array}$ & $\begin{array}{l}6.84 \\
(3)\end{array}$ \\
\hline \multirow{3}{*}{$\begin{array}{l}E S T 5^{3} \\
E S T 6^{1} \\
E S T 6^{2} \\
\text { average }\end{array}$} & \multirow{3}{*}{$\begin{array}{l}0.286 \\
0.000 \\
1.000\end{array}$} & & \multirow{3}{*}{$\begin{array}{l}0.164 \\
0.000 \\
1.000\end{array}$} & & \multirow{3}{*}{$\begin{array}{l}0.230 \\
0.260 \\
0.740\end{array}$} & & \multirow{3}{*}{ - } & \multirow{3}{*}{-} \\
\hline & & 0.000 & & 0.000 & & 0.385 & & \\
\hline & & 0.272 & & 0.227 & & 0.523 & & \\
\hline
\end{tabular}

*: $0.05<P<0.01 ;{ }^{* *}: P<0.001$.

- 1) Mutations can produce changes in the amino acid sequence of polypeptide chains affecting the specific activity (null alleles or alleles with a very slight expression).

- 2) Lower amounts of enzymatic molecules with the same structure are possibly a consequence of:

a) a regulatory gene;

b) different factors in the environment which produce the activation (or inactivation) of certain regulatory gene(s);

c) the existence of chromosome inversions fixed in this population that silence these loci by position effects;

The first hypothesis implies that alternative alleles for 3 out of 6 loci analysed are fixed in different populations. However, the most common situation among conspecific populations is that 1 allele is the most frequent in almost all of them (Lewontin, 1979). Besides, this hypothesis seems to be untenable according to the parsimony principle.

The hypothesis 2a implies a mutation affecting only a single gene (controlling $E S T 1$ to EST 3 loci) which seems to be a simpler and more likely explanation, though $2 \mathrm{~b}$ and $2 \mathrm{c}$ are also acceptable.

The hypothesis $2 \mathrm{~b}$ is plausible because esterases are enzymes frequently acting on external substrates proceeding from ingestion. The precise plant species that constitutes this grasshopper's food in Argentina is not known. Possible candidates are annual plants associated with species of the genus Larrea (creosote bush) (Otte and Joern, 1975; Wallner, 1987). As TU and both SL populations are located in different phytogeographic provinces, it is expected that the food supply exploited 
will not be the same. In fact, $L$ divaricata is widely distributed over the arid and semiarid regions in Argentina, but morphological differences are readily observed between plants at different altitudes. This may be a consequence of both genetical and physiological adaptations (Hunziker, personal communication). The plants associated with the creosote bush which constitue $T$ pallidipennis food are also expected to adapt to the corresponding environment. Therefore, distinct enzyme expression between the orthopterans feeding upon them is not surprising.

The hypothesis $2 \mathrm{c}$ is based on the high frequency of inversion polymorphisms and chromosomal differentiation among $T$ pallidipennis populations (Vaio el al, 1979; Goñi et al, 1985; Confalonieri, 1988; Confalonieri and Colombo, 1989). A similar kind of differentiation between the populations reported here was also evident when chromosome investigation was carried out (Confalonieri et al, submitted). The 3 populations were polymorphic for 3 centric shifts which involved 4 medium chromosomes; when they were statistically compared, differences with respect to inversion frequencies were highly significant among all populations except SL ones. Moreover, some chromosome arrangements were at high frequencies in TU and absent or at very low frequencies in $\mathrm{SL}_{1}$ and $\mathrm{SL}_{2}$, respectively. Therefore, these results are in agreement with the last hypothesis (2c) because if 2 populations have different fixed inversions, or are of very different frequencies, position effects are not an unexpected phenomena. Finally, inversion frequencies from 15 populations (including $\mathrm{TU}, \mathrm{SL}_{1}$ and $\mathrm{SL}_{2}$ from Argentina) were correlated in a very significant fashion with altitude (Confalonieri and Colombo, 1989; Confalonieri, in preparation), suggesting the action of natural selection in the maintenance of these polymorphisms. Therefore, as TU and both SL populations have very different inversion frequencies, most probably as a result of living at different altitudes, their chromosomal variation might also be related to genetical differentiation.

\section{ACKNOWLEDGMENTS}

The authors wish to express their sincere gratitude to $H$ Hunziker for his guidance, constant encouragement and critical reading of the manuscript and to PC Colombo for his generousity in providing material from Tucumán. We also thank the anonymous referees for their valuable suggestions. The financial support from Consejo Nacional de Investigaciones Cientificas y Técnicas, Secretaria de Ciencia y Técnica (Argentina) through grants to $\mathrm{H}$ Hunziker and A Naranjo is also acknowledged.

\section{REFERENCES}

Cabrera AL, Willink A (1973) Biogeografica de América Latina. Org Est Amer Washington, DC

Chapco W, Bidochka MJ (1986) Genetic variation in prairie population of Melanoplus sanguinipes, the migratory grasshopper. Heredity, 56, 397-408

Cladera JL (1981) Genetica de alozimas en Ceratitis capitata. I. Dos alelos de la esterasa pupal. Mendeliana, 5, 33-38

Confalonieri VA (1988) Effects of centric shift polymorphisms on chiasma conditions in Trimerotropis pallidipennis. Genetica, 76, 171-179 
Confalonieri VA, Colombo PC (1989) Inversion polymorphisms in Trimerotropis pallidipennis: Clinal variation along an altitudinal gradient. Heredity, 62, 107112

Cordeiro AR (1974) Varibilidade e regulacao genética nos processos evolutivos. Tese para conc Prof Titular. Dep Genét Univ Fed Rio Grande do Sul. Porto Alegre

Gill P (1981) Heterozygosity estimates in the grasshopper Chorthippus brunneus (Thunberg). Heredity, 46, 269-272

Goñi B, De Vaio E, Beltram M, Leira MS, Crivel M, Panzera F, Castellanos P, Basso A (1985) Geographic patterns of chromosomal variation in populations of the grasshopper (Trimerotropis pallidipennis) from Southern Argentina. Can $J$ Genet Cytol 27, 259-271

Halliday RB, Barton NH, Hewitt GM (1983) Electrophoretic analysis of a chromosomal hybrid zone in the grasshopper Podisma pedestris. Biol J Linn Soc, 19, 51-62

Hewitt GM (1979) Orthoptera: Grasshoppers and crickets. Animal Cytogenetics. Vol 3. Stuttgart: Gebruder Borntraeger, Berlin, $170 \mathrm{p}$

John B (1983) The role of chromosome change in the evolution of orthopteroid insects. In: Chromosomes in evolution of eukariotic groups, (Sharma AK; Sharma AM, eds), I, 1-114. CR C Press, Florida

Lewontin RC (1979) La base genética de la evolución. Ediciones Omega SA Barcelona

Mesa A (1971) Polimorfismo cromosómico en Trimerotropis pallidipennis (Orthoptera-Acridoidea-Oedipodinae). Rev Peru Entom, 14, 2

Moran C, Wilkinson P, Shaw C (1980) Allozyme variation across an arrow hybrid zone in the grasshopper Caledia captiva. Heredity, 44, 69-81

Neimann-Sorensen A (1956) Blood groups and breed structure as exemplified by three Danish breeds. Acta Agric Scand 6, 115-137

Nevo E, Belles A, Ben-Shlomo R (1984) Evolutionary dynamic of genetic diversity. Lecture Notes in Biomathematics. (Mani GS, ed) 53, 13-213

Otte BO, Joern 1 (1975) Insect territoriality and its evolution: Population studies of desert grasshoppers on creosote bushes. J Anim Ecol 44, 29-54

Saidman BO, Naranjo CA (1982) Variaciones de esterasas en poblaciones de Prosopis ruscifolia (Leguminosae). Mendeliana, 5, 61-70

Schaal BA, Anderson WW (1974) An outline of techniques for starch gel electrophoresis of enzymes from the American oyster (Crassostrea virginica). Gem Georg Mar Sci Ctr Tech Rpt Ser No 74, 3

Vaio ES de, Goñi B, Rey C (1979) Chromosome polymorphisms in populations of the grasshopper Trimerotropis pallidipennis from Southern Argentina. Chromosoma (Bers) 71, 371-386

Wallner WE (1987) Factors affecting insect population dynamics: Differences between outbreak and non-outbreak species. Ann Rev Entomol 32, 317-340

White MJD (1973) Animal Cytology and Evolution (3rd Ed). Cambridge Univ Press, New York 